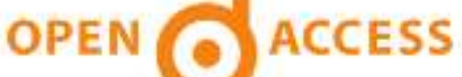

\section{International Journal of Applied Sciences and Biotechnology}

\author{
A Rapid Publishing Journal
}

\section{ISSN 2091-2609}

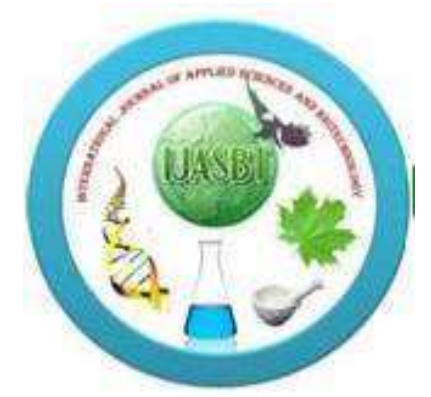

\section{Available online at:}

http://www.ijasbt.org

http://www.nepjol.info/index.php/IJASBT/index

\section{Indexing and Abstracting}

CrossRef, Google Scholar, Global Impact Factor, Genamics, Index Copernicus, Directory of Open Access Journals, WorldCat, Electronic Journals Library (EZB), Universitätsbibliothek Leipzig, Hamburg University, UTS (University of Technology, Sydney): Library, International Society of Universal Research in Sciences (EyeSource), Journal Seeker, WZB, Socolar, BioRes, Indian Science, Jadoun Science, Jour-Informatics, Journal Directory, JournalTOCs, Academic Journals Database, Journal Quality Evaluation Report, PDOAJ, Science Central, Journal Impact Factor, NewJour, Open Science Directory, Directory of Research Journals Indexing, Open Access Library, International Impact Factor Services, SciSeek, Cabell's Directories, Scientific Indexing Services, CiteFactor, UniSA Library, InfoBase Index, Infomine, Getinfo, Open Academic Journals Index, HINARI, etc.

\section{CODEN (Chemical Abstract Services, USA): IJASKD}

Vol-2(4) December, 2014

Impact factor*: $\mathbf{1 . 4 2 2}$

Scientific Journal Impact factor ${ }^{\#}: 3.419$

Index Copernicus Value: $\mathbf{6 . 0 2}$

SEM-Biotech

Publishing

*Impact factor is issued by Universal Impact Factor. Kindly note that this is not the IF of Journal Citation Report (JCR).

"Impact factor is issued by SJIF INNO SPACE. 


\title{
EVALUATION OF SNAKE GOURD (TRICHASANTHES ANGUINA L) TEST HYBRIDS COMPARING WITH FOUR POPULAR CHECKS
}

\author{
M.M. Haque ${ }^{1}$, M. S. Uddin ${ }^{1}$, H. Mehraj ${ }^{2 *}$ and AFM Jamal Uddin ${ }^{3}$ \\ ${ }^{1}$ Supreme Seed Company Limited, Research \& Development (Vegetable) Farm, Bhaluka, Mymensingh, Bangladesh \\ ${ }^{2}$ The United Graduate School of Agricultural Sciences, Ehime University, 3-5-7 Tarami, Matsumaya, Ehime 790-8556, Japan \\ ${ }^{3}$ Department of Horticulture, Sher-e-Bangla Agricultural University, Dhaka-1207, Bangladesh \\ *Corresponding author's email: hmehraj02@yahoo.com
}

\begin{abstract}
An experiment was conducted at Research and Development (Vegetable) Farm, Supreme Seed Company Limited, Mymensingh in $20^{\text {th }}$ March to $14^{\text {th }}$ June, 2013 to evaluate performance of eight snake gourd genotypes. Among snake gourd genotypes four were test hybrid viz. SG1001, SG1002, SG1003 and SG1004 (from the seven inbreed lines) and four were checks (three from local market and one from BADC) viz. SUPREMA, RUNNER, SURMA, ZUM LONG. Wide ranges of variability were found in the studied characters among the genotypes. Maximum total number of fruits was found from SUPREMA (235.3/plot) which was statistically similar to RUNNER (201.3/plot) while minimum from ZUM LONG (24.7/plot) that was used as check. SG1002 genotype provided maximum marketable yield (49.6 kg/plot) and minimum from ZUM LONG (30.7 kg/plot). SUPREMA, SG1002, SG1001 and RUNNER genotypes showed better performance in respect of number of fruits/plant, fruit length, individual fruit weight, yield/plot and some other characters. Flowering period was significantly correlated with yield contributing characters. Number of fruits/plant, total number of fruits/plot and individual fruit weight was significantly positively correlated with yield of snake gourd.
\end{abstract}

Key words: Trichosanthes cucumerina; genotypes; flowering and yield

\section{Introduction}

Snake gourd (Trichasanthes anguina $\mathrm{L}$ ) belongs to Cucurbitaceae family having chromosome number, $2 \mathrm{n}=22$ (Chakrabarti, 1982), day neutral herbaceous and climbing type vegetable crops. In Bangladesh it is usually grown in field and homestead garden. As a result, it can meet up the vegetable demand during early Kharif season when there exists an acute shortage of vegetable in Bangladesh. It plays a vital role in mitigating vegetable demand during the lean period of vegetable supply in Bangladesh. Snake gourd is one of the leading summer vegetables. In addition, it has got tremendous export potentiality because of its excellent keeping quality (Podder et al., 2010). The total production of snake gourd during 2009 to 2010 was 30339 MT on the area of 15741 acres of land (BBS 2009 to 2010) which indicates the low yield potentiality as compared to India and Thailand. Lack of high yielding variety is a major reason for low yield of this crop in Bangladesh. Moreover, no systematic research of this crop has yet been carried out in Bangladesh. Therefore, present study was undertaken for evaluation of snake gourd test hybrids for selecting the best one(s).

\section{Materials and Methods}

An experiment was conducted at Research and Development (Vegetable) Farm, Supreme Seed Company Limited, Bhaluka, Mymensingh in $20^{\text {th }}$ March to $14^{\text {th }}$ June, 2013. Four test hybrid viz. SG1001, SG1002, SG1003 and SG1004 (from the seven inbreed lines) and four checks (three from local market and one from BADC) viz. SUPREMA, RUNNER, SURMA, ZUM LONG were used in the experiment following RCBD design with three replications. The unit plot size was $7.0 \times 1.2 \mathrm{~m}^{2}$ and spacing was $1.2 \times 1.75 \mathrm{~m}^{2}$ and each plot contains 12 plants. Three seeds were sown in each pit and after germination rest seedlings were removed leaving one healthy plant. Seeds of the eight genotypes were first allowed to soak in water for 24 hours. The soaked seeds were then sown directly to the pit. Manures and fertilizers were applied at the rate of Cowdung $25 \mathrm{t} / \mathrm{ha}$, Urea $250 \mathrm{~kg} / \mathrm{ha}$, TSP $100 \mathrm{~kg} / \mathrm{ha}$, MP 175 $\mathrm{kg} / \mathrm{ha}$, Gypsum $100 \mathrm{~kg} / \mathrm{ha}, \mathrm{MgSO}_{4} 35 \mathrm{Kg} / \mathrm{ha}$, Zinc oxide 5 $\mathrm{kg} / \mathrm{ha}$ and Borax $5 \mathrm{~kg} / \mathrm{ha}$. Total Cowdung, TSP, Gypsum, MgSO4, Zinc oxide, Borax, Regent and one fifth of Urea \& MP were applied during final land preparation. The rest Urea \& MP were applied in four splits. Data were collected 
on days to female flowering, days to male flowering, node number at first female flowering, node number at first male flowering, days to first harvesting, number of fruits/plant, fruit length, fruit diameter total number of fruits, individual fruit weight and yield.

Collected data were analyzed statistically using MSTAT-C computer package program. The mean values of all the characters were calculated and analysis of variance was performed. The significance of the difference among the treatment means was estimated by the Duncan Multiple Range Test (DMRT) at 5\% level of probability (Gomez and Gomez, 1984).

\section{Results and Discussion}

\section{Flowering Characteristics}

Significant variations were recorded among genotypes on flowering characteristics pertaining to days to female flowering, days to male flowering, node number at first female flowering, node number at first male flowering and days to first harvesting (Table 1). Late female flowering was found from RUNNER (45.3 days) which was statistically identical with ZUMLONG (44.7 days) and SG1004 (44.3 days) while early from SUPREMA (36.7 days) that was statistically identical with SG10002 (38.7 days) but late male flowering was also found from RUNNER (45.0 days) which was statistically identical with SG1004 (43.3 days) while early male flowering from SUPREMA (40.3) which was statistically identical with SG1002 (41.0 days), SG1003 and ZUM LONG (41.3 days) (Table 1). Maximum number of nodes at female flowering was found from RUNNER and SG1003 (19.7) which was statistically identical with SG1002, SG1004, SURMA and ZUM LONG while minimum from SG1001 (16.3 days) but maximum number of nodes at first male flowering was found from SG1002 and SG1004 (14.0) which was statistically identical with all of the genotypes except SUPREMA that had provided minimum number of nodes at first male flowering (9.0). Early harvesting was done from SG1002 (47.7 days) while late harvesting from SG1003 (59.0 days) which was statistically identical with SG1003 (58.0 days) and RUNNER (57.0 days) (Table 1). Saha et al. (1986) reported 4.6 to 8.8 nodes for male flower bearing among the pumpkin genotypes. Prasad and Singh (1989) found low genotypic and phenotypic variance for node order of first male flower open (2.7-7.4) in ribbed gourd.

\section{Fruit Characteristics}

Number of fruits, fruit length and fruit diameter was varied significantly among the genotypes. However, maximum number of fruits was found from SUPREMA (58.7/plant) which was statistically identical with RUNNER (50.3/plant) while minimum from ZUM LONG (24.7/plant) which was statistically identical with SG1004 (29.3/plant). Longest fruit was found from SG1001 $(43.3 \mathrm{~cm})$ which was statistically similar with SG1002, SG1003, SG1004 and RUNNER while shortest from SURMA $(28.0 \mathrm{~cm})$ which was statistically identical with ZUM LONG $(31.7 \mathrm{~cm})$. Maximum fruit diameter was found from the genotype ZUM LONG $(4.7 \mathrm{~cm})$ while minimum from SUPREMA $(3.7 \mathrm{~cm})$. These results are in accordance with the findings obtained by Varghese (1991). The weight of fruit varied significantly among the genotype and the line RUNNER performed the best in terms of individual weight (Table 2).

\section{Yield characteristics}

Significant variation was found in total number of fruits, individual fruit weight and yield of snake gourd genotypes. Maximum total number of fruits was found from SUPREMA (235.3/plot), which was statistically identical with RUNNER (201.3/plot) whereas minimum from ZUM LONG (98.7/plot). Maximum individual fruit weight was found from RUNNER (260.0 g) while minimum from SURMA (191.7 g). Maximum yield was found from SG1002 (49.6 kg/plot) which was statistically identical with SUPREMA genotype $(44.3 \mathrm{~kg} / \mathrm{plot})$ while minimum from ZUM LONG (29.4 kg/plot) which was statistically identical with SURMA (30.7 kg/plot) and SG1004 (33.0 kg/plot) (Table 2). Variations for yield per plant was also recorded in water melon (Chezhiyan, 1984), bottle gourd (Rahman et al., 1991) musk melon (Swamy et al., 1984) and pumpkin (Rana et al., 1986; Shah et al., 1992).

\section{Correlation Coefficients}

From the correlation study it was found that days to female flowering was significantly positively correlated at $1 \%$ level of probability with days to first harvesting $\left(.821^{* *}\right)$ while at $5 \%$ level of probability it was significantly positively correlated with days to male flowering $\left(.480^{*}\right)$, node number at first female flowering $\left(.504^{*}\right)$ and individual fruit weight $\left(.475^{*}\right)$. Days to male flowering showed significant positive correlation with individual fruit weight $\left(.450^{*}\right)$ only at $5 \%$ level of significance. Number of fruits/plat showed significant positive relation with total number of fruits/plot $\left(1.00^{*}\right)$ and yield/plot $\left(.816^{* *}\right)$ with $1 \%$ level of significance (Table 3). Mehraj (2013) was also studied correlation among the different phenotypic characteristics of strawberry and found wide ranges of relationship among the characters. Increase in fruit length and diameter resulted in increase in fruit weight which ultimately increased the total yield/plant. Fruit weight and fruits per plant also having very high positive direct effect upon yield, which is also evident from path co-efficient analysis. Correlation analysis involves a method to find out the direct, indirect and no relationship among the characters. Correlation coefficients indicated an association among the characters (Shekhavat et al., 2005). Thus, these characters are important yield attributes to be reckoned in the selection criteria for improvement. Similarly, several experiments were also conducted for the correlation analysis (Oad et al., 2002; Rana and Chauhan, 2003). Hence, direct selection for traits like fruit weight and number of fruits/plant could be effective for improvement of the yield. Traits days to first 
male flower, days to first female flower and node number at first female flower appearance exhibited negative correlation co-efficient with yield. (Bhave et al., 2003). The above findings indicated that the lower the node at which first male or female flower appeared the higher and earlier would be the yield. Joshi et al. (1981) observed similar findings in cucumber and stated that the number of nodes to the first pistilate flower is reasonably a good measure of earliness. A strong negative correlation of ascorbic acid and total carotenoids with fruit weight indicated that small fruited genotypes are rich in ascorbic acid and total carotenoids and are more nutritions (Tendulkar, 1997)

Table 1: Flowering characteristics of the snake gourds genotypes ${ }^{X}$

\begin{tabular}{|c|c|c|c|c|c|c|c|c|c|c|}
\hline \multirow{3}{*}{$\begin{array}{c}\begin{array}{c}\text { Snake gourd } \\
\text { genotypes }\end{array} \\
\text { SG1001 }\end{array}$} & \multicolumn{4}{|c|}{ Days to flowering } & \multicolumn{4}{|c|}{ Node number at first flowering } & \multirow{2}{*}{\multicolumn{2}{|c|}{$\begin{array}{c}\text { Days to first } \\
\text { harvesting }\end{array}$}} \\
\hline & \multicolumn{2}{|c|}{ female } & \multicolumn{2}{|c|}{ male } & \multicolumn{2}{|c|}{ female } & \multicolumn{2}{|c|}{ male } & & \\
\hline & 39.7 & $\mathrm{c}$ & 42.0 & $\mathrm{bc}$ & 16.3 & $\mathrm{c}$ & 12.7 & $\mathrm{a}$ & 51.7 & $\mathrm{~b}$ \\
\hline SG1002 & 38.7 & $\mathrm{~cd}$ & 41.0 & $\mathrm{c}$ & 18.3 & $a b$ & 14.0 & $\mathrm{a}$ & 47.7 & $\mathrm{c}$ \\
\hline SG1003 & 42.7 & $\mathrm{~b}$ & 41.3 & $\mathrm{c}$ & 19.7 & $\mathrm{a}$ & 13.7 & a & 59.0 & $\mathrm{a}$ \\
\hline SG1004 & 44.3 & $a b$ & 43.3 & $a b$ & 18.0 & $a b c$ & 14.0 & $\mathrm{a}$ & 58.0 & $\mathrm{a}$ \\
\hline SUPREMA & 36.7 & $\mathrm{~d}$ & 40.3 & $\mathrm{c}$ & 17.7 & $\mathrm{bc}$ & 9.0 & b & 51.0 & $\mathrm{~b}$ \\
\hline RUNNER & 45.3 & $\mathrm{a}$ & 45.0 & a & 19.7 & a & 11.7 & $\mathrm{a}$ & 57.0 & $\mathrm{a}$ \\
\hline SURMA & 39.0 & $\mathrm{c}$ & 42.0 & $\mathrm{bc}$ & 18.3 & $a b$ & 13.3 & $\mathrm{a}$ & 53.0 & b \\
\hline ZUM LONG & 44.7 & $a b$ & 41.3 & $\mathrm{c}$ & 19.3 & $a b$ & 13.3 & $\mathrm{a}$ & 53.0 & $\mathrm{~b}$ \\
\hline LSD & 2.1 & & 2.0 & & 1.8 & & 2.4 & & 3.3 & \\
\hline $\mathrm{CV} \%$ & 2.9 & & 2.7 & & 5.6 & & 10.7 & & 3.5 & \\
\hline
\end{tabular}

${ }^{\mathrm{X}}$ In a column, means having similar letter(s) are statistically similar and those having dissimilar letter(s) differ significantly at 0.05 level of probability

Table 2: Fruit and yield characteristics of snake gourd genotypes ${ }^{X}$

\begin{tabular}{|c|c|c|c|c|c|c|c|c|c|c|c|c|}
\hline \multirow{2}{*}{$\begin{array}{l}\text { Treatment } \\
\text { SG1001 }\end{array}$} & \multicolumn{2}{|c|}{$\begin{array}{l}\text { Number of } \\
\text { fruits/plant }\end{array}$} & \multicolumn{2}{|c|}{$\begin{array}{l}\text { Fruit } \\
\text { length } \\
(\mathrm{cm})\end{array}$} & \multicolumn{2}{|c|}{$\begin{array}{c}\text { Fruit } \\
\text { diameter } \\
(\mathrm{cm})\end{array}$} & \multicolumn{2}{|c|}{$\begin{array}{l}\text { number of } \\
\text { fruits/plot }\end{array}$} & \multicolumn{2}{|c|}{$\begin{array}{l}\text { Individual fruit } \\
\text { weight }(\mathrm{g})\end{array}$} & \multicolumn{2}{|c|}{ Yield (kg/plot) } \\
\hline & 39.3 & $\mathrm{c}$ & 43.3 & $\mathrm{a}$ & 4.0 & $a b$ & 156.3 & $\mathrm{c}$ & 243.3 & $a b$ & 34.4 & $\mathrm{bc}$ \\
\hline SG1002 & 49.0 & $\mathrm{~b}$ & 40.3 & $a b$ & 4.1 & $a b$ & 196.0 & $\mathrm{~b}$ & 210.0 & $a b$ & 49.6 & $\mathrm{a}$ \\
\hline SG1003 & 39.7 & $\mathrm{c}$ & 40.7 & $a b$ & 4.0 & $a b$ & 157.0 & $\mathrm{c}$ & 213.3 & $a b$ & 42.1 & $a b$ \\
\hline SG1004 & 29.3 & de & 38.0 & $a b$ & 4.6 & $\mathrm{a}$ & 117.0 & de & 250.0 & $a b$ & 33.0 & $\mathrm{c}$ \\
\hline SUPREMA & 58.7 & $\mathrm{a}$ & 37.0 & $\mathrm{bc}$ & 3.7 & $\mathrm{~b}$ & 235.3 & $\mathrm{a}$ & 193.3 & $\mathrm{~b}$ & 44.3 & $\mathrm{a}$ \\
\hline RUNNER & 50.3 & $a b$ & 41.3 & $a b$ & 3.9 & $a b$ & 201.3 & $a b$ & 260.0 & $\mathrm{a}$ & 42.4 & $a b$ \\
\hline SURMA & 35.7 & $\mathrm{~cd}$ & 28.0 & $\mathrm{~d}$ & 4.2 & $a b$ & 141.3 & $\mathrm{~cd}$ & 191.7 & $\mathrm{~b}$ & 30.7 & $\mathrm{c}$ \\
\hline ZUM LONG & 24.7 & $\mathrm{e}$ & 31.7 & $\mathrm{~cd}$ & 4.7 & $\mathrm{a}$ & 98.7 & $\mathrm{e}$ & 256.7 & $\mathrm{a}$ & 29.4 & $\mathrm{c}$ \\
\hline LSD & 8.9 & & 5.6 & & 0.9 & & 35.8 & & 61.8 & & 9.1 & \\
\hline $\mathrm{CV} \%$ & 12.5 & & 8.5 & & 12.4 & & 12.5 & & 15.5 & & 13.6 & \\
\hline
\end{tabular}

${ }^{\mathrm{X}}$ In a column, means having similar letter(s) are statistically similar and those having dissimilar letter(s) differ significantly at 0.05 level of probability

Table 3: Correlation of eleven yield contributing characters on yield of eight snake gourd genotypes

\begin{tabular}{|c|c|c|c|c|c|c|c|c|c|c|c|}
\hline Ch. & 1 & 2 & 3 & 4 & 5 & 6 & 7 & 8 & 9 & 10 & 11 \\
\hline 1 & 1 & & & & & & & & & & \\
\hline 2 & $.480 *$ & 1 & & & & & & & & & \\
\hline 3 & $.504^{*}$ & .142 & 1 & & & & & & & & \\
\hline 4 & .276 & .219 & .169 & 1 & & & & & & & \\
\hline 5 & $.821^{* *}$ & .303 & $.448 *$ & .094 & 1 & & & & & & \\
\hline 6 & $-.495^{*}$ & -.103 & -.056 & $-.620 *$ & $-.476^{*}$ & 1 & & & & & \\
\hline 7 & $-.495 *$ & -.103 & -.056 & $-.620^{*}$ & $-.476 *$ & $1.00 * *$ & 1 & & & & \\
\hline 8 & -.285 & -.110 & .118 & -.327 & -.336 & $.816^{* *}$ & $.816^{* *}$ & 1 & & & \\
\hline 9 & $.475^{*}$ & $.450^{*}$ & .143 & .255 & .292 & -.329 & -.329 & -.321 & 1 & & \\
\hline 10 & .096 & .141 & -.093 & -.152 & -.026 & .376 & .376 & $.471 *$ & .161 & 1 & \\
\hline 11 & .277 & .126 & .094 & $.526^{*}$ & .21 & $-.635^{*}$ & $-.635^{*}$ & $-.540 *$ & $.665^{*}$ & $-.434 *$ & 1 \\
\hline
\end{tabular}

*Significant at 0.05 level (2-tailed); **Significant at 0.01 level (2-tailed)

Here, Ch.; studied characters; 1; days to female flowering, 2; days to male flowering, 3; node number at first female flowering, 4; node number at first male flowering, 5; days to first harvesting, 6; number of fruits/plant, 7; total number of fruits/plot, 8; yield/plot, 9; individual fruit weight, 10; fruit length and 11; fruit diameter 


\section{Conclusion}

The genotype SUPREMA, SG10021, SG100 and RUNNER showed better performance in respect of number of fruits, fruit length, fruit weight and yield contributing characters. Fruit yield/plant exhibited significant positive correlation with number of fruits/plant and fruit length. In general, genotypic correlation coefficients were higher than the corresponding phenotypic correlation coefficients suggesting that environmental influence reduces relationship between yield and yield contributing characters of snake gourd.

\section{References}

BBS (2009-2010) Year Book of Agricultural Statistics of Bangladesh, 2010. Bangladesh Bureau of Statistics. Ministry of Planning. Govt. of the people's Republic of Bangladesh. Dhaka.

Bhave SG, Mehta JL, Bendale VW, Mhatre PP and Pethe UB (2003) Character association and path co-efficient analysis of bitter gourd ((Momordica charantia L.). Orissa J. Horti. 31(1): 44-46.

Chezhgiyan N (1984) Studies on the performance of certain indigenous varieties of water melon (citrullus) vulgaris schard). South Indian Hort. 32(3):,163-166.

FAO (Food and Agricultural Organization) Soil Servey Project of Bangladesh (1971) Soil Res. Tech. Tep. Pp 101-159.

Joseph S (1978) Genetic variability and correlation studies in snake gourd (Trichosanthes anguina L). M.S.C. Thesis. Kerala Agricultural University. Trissur, kerala. India.

Joshi S, Joshi MC, Singh B and Vishnoi AK (1981) Genotypic and phenotypic variability in cucumber (Cucumis sativus $\mathrm{L}$.). Veg. Sci. 8(2): 114-119.

Mehraj H (2013) Response of Strawberry Germplasm to Organic Fertilizers. MS Thesis, July 2013. Department of Horticulture, Sher-e-Bangla Agricultural University, Dhaka-1207, Bangladesh. pp. 81-85.

Oad FC, Samo MAS, Oad NL and Chandio GQ (2002) Relationship of physiological, growth and yield contributing parameters of locklodged rice ratoon crop. Journal of Applied Sciences 2(4): 429-432. DOI: 10.3923/jas.2002.429.432

Podder R, Rasul MG, Islam AKMA, Mian MAK and Ahmed JU (2010) Combining ability and Heterasis in Snake gourd (Tricosanthes Cucumminata L). Bangladesh J. Pl. Breed. Genet. 23 (2): 01-06.

Rahman MM, Dey SK and Wazuddin M (1990) Yield, yield components and plant characters of several bitter gourd, ribbed gourd. bottle gourd and sweet gourd genotypes. BAU Res. Prog. 4: 117-127.

Rahman MM, Dey SK and Wazuddin M (1991) Study of yield, yield components and vine characters of some cucurbit genotypes. BAU Res. Prog. 5A: 75-86.

Rana MI and Chauhan HQI (2003) Relationship between Different Growth and Yield Parameters in Maize under Varying Levels of Phosphorus. Journal of Biological Sciences 3(10): 921-925. DOI: 10.3923/jbs.2003.921.925

Rana TK, Vashistha RN Pandita ML (1986) Genetic variability and heritability studies in pumkin. haryana. J. of Hort. Sci. 15(1-2): 71-75.

Saha MC, Begum RA and Hamid MM (1986) Preliminary evaluation of different pumpkin (Cucurbita moschata Duch expior.) lines. Annual Report. Vegetable section. BARI. Joydebpur.

Shekhavat AKS, Singh B, Yadav JR and Srivastava JP (2005) Character association in okra (Abelomochus esculentus Monech). Plant Archies 5: 289-291.

Swamy KRM. Dutta OP. Ramachander PR. Wahi SD (1984) Interrelations hips among yield and other quantitative characters in musk melon (Cucumis melo L.). South Indian. Hort. 32(6): 334-339.

Tendulkar Sachin (1997) Heterosis, combining ability and gene action in bitter gourd (Momordica charantia L.) Ph.D. thesis PG School, IARI, New Delhi-12.

Uddin Z, Khatoon R and Rashid MA (2007-2008) Evaluation of snake gourd germplasm. Annual Research Report on Horticulture crops. P - 52-54. 